\title{
EDITORIAL
}

\section{Notes from the Editors}

\section{Nina Volckmar \& Einar Sundsdal}

September 19-20, 2018, the Seventh Nordic Conference on the History of Education was held in Trondheim, Norway. All the previous Nordic Conferences on the History of Education have been held in Sweden. Thus, the Department of Education and Lifelong Learning, Norwegian University of Science and Technology (NTNU) was especially delighted to welcome researchers from Sweden, Denmark, Finland, Iceland, the Faroe Islands, the Netherlands, Switzerland, Belgium, United Kingdom, China, and Norway, altogether more than 100 participants in 22 sessions.

The conference was organized as a collaboration between the Department of Education and Lifelong Learning (NTNU), Nordic Journal of Educational History and the Nordic Network for History of Education. The conference took place in historical Trondheim, with organ recital in Nidaros Cathedral and dinner at the Archbishop's Palace as cultural highlights.

History of education is today an interdisciplinary research field that includes researchers from various academic disciplines and has a broad thematic scope. The overall theme of the Seventh Nordic Conference on the History of Education-Education and society in change-was wide and invited multiple reflections and analyses. The sessions covered a time span from early modern to contemporary times and different levels of schooling, from primary and secondary education to vocational and higher education. Also, a range of themes were addressed, such as education and violence, fascist education and democracy, peace education, school architecture, educational places and forms, teaching materials, teacher education, religion, Bildung, social mobility, debates on "school crisis", and childhood and knowledge in Nordic coastal communities. Accordingly, the sessions reflected a broad scope of methodological approaches to the history of education as a research field. The Nordic Conference on the History of Education continues to serve as a vital and important conversational space for collective reflections about education, past and present.

All participants at the conference were invited to submit their paper for consideration for publication in this special issue. Altogether six contributions were accepted for publication. We would like to thank the reviewers for their invaluable contribution to the making of this issue.

The first article, "The Rhetorical Education of Isocrates and the Exemplary in Teaching: Overcoming the 'Learningfication of Education"' is written by Lars Petter Torjussen, Associate Professor at the University of Bergen. The article argues that the rhetorical education of Isocrates can serve as a vital alternative to today's dominating trend of outcome-based education. Torjussen suggests that educational theory needs to rediscover the roots of the didactical tradition in rhetoric. 
The next four articles are all about education in a Swedish context. "Skola inför rätta: Tolkning och använding av skolhistoria i samtidens debatt om framtidens samhälle och skola" [School on trial: Interpretation and use of school history in contemporary debate about the future of society and school] is written by Johan Samuelsson, Lecturer at Karlstad University. It is about how education and the Swedish School Commission become resources in the discussion on how society and education should be developed. Three historical narratives on the Swedish School Commission are analysed and show how critical historical narratives are used to legitimise political change.

In "Kolonisatör eller turist? Frågor och arbetsuppgifter i svenska historieläromedel under en tid av kunskapsideologisk förhandling" [Coloniser or tourist? Questions and exercises in Swedish history textbooks, 1927-2015] Anders Persson, Lecturer at Dalarna University, deals with History as a Swedish school subject. Here Persson investigates which different approaches to history can be seen in questions and exercises to pupils in history textbooks published 1927-2015.

"'Från pappas lydige Henric:' Pedagogiska perspektiv på det tidiga 1800-talets bildningresande" ["From daddy's obedient Henric:" Pedagogical perspectives on educational travel of the early 1800's] is written by Associate Professor Juvas Marianne Liljas, Dalarna University. She analyses travel letters of the Swedish industrial gentry Johan Henrik Munktell written between 1828 and 1830. Liljas argues that travel narratives are significant sources for how education was arranged in pre-industrial landscapes.

"Reflexiv internationalisering: Utvecklingsfrågor som ett bildningsområde för en folkhögskola i takt med tiden" [Reflective internationalisation: Development issues as an educational area for folk high schools in step with the times] is written by Sofia Österborg Wiklund, Assistant Lecturer at Linköping University. The article is about the Swedish Folk High School and its long-term engagement in less-developed countries. Wiklund analyses changes in discourses on internationalisation in Tidskrift för svenska folkhögskolan [Journal for the Swedish Folk High School] 1970-1989.

The last article in this special issue, "The Faroese Path to a Comprehensive Education System," is written by Professor Nina Volckmar, Norwegian University of Science and Technology. The article traces the Faroese path to a comprehensive education system, following the winding road from Norwegian heritage to Danish rule and an increasing degree of autonomy. Volckmar argues that changes in governance structures and economic conditions are determinant in the degree to which the Faroese themselves have taken responsibility for the development of the Faroese education system.

These six articles in this special issue clearly reflect the diversity of themes and methodological approaches at the conference. However, four of the articles are written by Swedes and relate largely to a Swedish context. The remaining two are written by Norwegian researchers. In the future, the Nordic Journal of Educational History should aim at attracting researchers from the whole Nordic region.

Finally, the guest editors would like to thank the Nordic Journal of Educational History, and especially Senior Editor Henrik Åström Elmersjö, for a pleasant and productive collaboration on the publication of this special issue. 